\title{
ANALISIS FAKTOR-FAKTOR YANG MEMPENGARUHI PERINGKAT OBLIGASI PADA PERUSAHAAN-PERUSAHAAN SEKTOR PERBANKAN YANG TERDAFTAR DI BURSA EFEK INDONESIA TAHUN 2015-2018
}

\author{
Tannia, Aryanilo, Edward \\ Fakultas Ilmu Sosial dan Humaniora, Universitas Bunda Mulia \\ E-mail : tannia@bundamulia.ac.id
}

\begin{abstract}
Bond is one financial instrument that are interest to investors, in making decisions to buy bond the rating of bond can be the basis to buy bonds. The rating of bond can be seen from the ranking institution like PEFINDO. This study was conducted to analyze factor that influence the rating of bond in banking companies listed on Indonesia Stock Exchange period 2015 to 2018. Suspected factor that influence the rating of bonds is Capitalization, Liquidity, Profitability. Research Method used Multiple Linear Regression, hypothesis testing using $F$ test and T test with level of significance 5\% ( $\alpha=$ 0,05). Type data that used is secondary data. In this study the sample is 22 banking companies Data was obtained from Indonesia Stock Exchange official site. The sampling technique is determined using targeted sampling (purposive sampling). The result form hypothesis testing is caplitalization, liquidity, profitability not affect the rating of bonds partially and simultaneously.
\end{abstract}

Keywords: The Rating of Bonds; Capitalization; Liquidity; Profitability.

\section{PENDAHULUAN}

Dalam pelaksanaan pembangunan ekonomi nasional suatu negara diperlukan pembiayaan baik dari pemerintah dan masyarakat, pasar modal merupakan salah satu sumber alternative pendanaan baik bagi pemerintah maupun swasta (Yenni, 2015). Pasar modal sebagaimana pasar pada umumnya adalah suatu tempat untuk mempertemukan penjual dan pembeli. Yang membedakannya dengan pasar lainnya adalah pada objek yang diperjualbelikan (Tavinayati, 2009: 1).

Menurut Irsan (2004) Pasar Modal dapat didefinisikan sebagai pasar yang memperjual belikan berbagai instrument keuangan (sekuritas) jangka panjang, baik dalam bentuk utang mauun modal sendiri yang diterbitkan oleh perusahaan swasta.

Dengan demikian pasar modal adalah sebuah tempat memperdagangkan efek yang diterbitkan lembaga dan profesi yang terkait dengan efek (Sholihin, 2010: 351).

Menurut Dahlan Siamat (2004:249) Perkembangan pasar modal di Indonesia dimulai ketika pemerintah Hindia Belanda mendirikan bursa efek di Jakarta (Batavia) pada akhir tahun 1912. Efek - efek yang didagangkan dalam bursa ini terdiri atas saham - saham dan obligasi yang diterbitkan perusahaan milik Belanda yang beroperasi di Indonesia, Obligasi pemerintah Hindia Belanda dan efek - efek Belanda lain. 
Instrumen yang ada di Pasar Modal pada prinsipnya adalah semua surat - surat berharga (efek) yang umum diperjualbelikan melalui pasar modal. Efek adalah setiap surat pengakuan utang, surat berharga komersial, saham, obligasi, sekuritas kredit, tanda bukti utang, rights, warrants, opsi/setiap derivatif dari efek. Sifat efek yang diperdagangkan dipasar modal (bursa efek) biasanya berjangka waktu panjang. Instrument yang paling umum diperjualbelikan melalui bursa efek di Indonesia saat ini adalah saham, obligasi, dan rights (Dahlan, 2004: 267)

Salah satu instrumen keuangan yang diperjualbelikan dan diminati yaitu obligasi. Obligasi adalah kontrak jangka panjang dimana peminjam setuju untuk melakukan pembayaran bunga dan pokok pinjaman, pada tanggal tertentu, kepada pemegang obligasi (Brigham, 2001).

Investor yang membeli obligasi mempunyai tujuan utama untuk memperoleh return (hasil) / yield yang diharapkan akan diterima di masa yang akan datang (Martono, 2001: 36). Bagi emiten, obligasi dianggap sebagai sekuritas yang aman karena biaya emisinya lebih murah daripada saham (Maharti, 2011).

Salah satu hal yang harus diperhatikan investor ketika akan membeli obligasi yaitu peringkat obligasi. Peringkat obligasi merupakan skala risiko dari semua obligasi yang diperdagangkan. Skala ini menunjukkan seberapa aman suatu obligasi bagi investor. Keamanan ini ditunjukkan dari kemampuan perusahaan dalam membayar bunga dan pelunasan pokok pinjaman (Agus Sunarjanto, 2013).

Menurut Raharja dan Sari (2008) peringkat obligasi sangat penting bagi investor karena mampu memberikan pernyataan informatif dan memberikan sinyal tentang kemungkinan kegagalan utang suatu perusahaan. Manfaat lain yang diperoleh investor dari peringkat obligasi adalah penghematan biaya dan waktu untuk melakukan analisis sendiri dan mendapatkan informasi secara langsung (Ang, 2007).

Menurut Grace (2018) dari artikel kontan.co.id yang menjelaskan "bunga obligasi teranyar emiten perbankan dipatok lebih tinggi". Oleh karena itu peneliti memilih obligasi sektor perbankan.

Masyarakat sebagai calon pemegang obligasi, tentunya akan mempertimbangkan matang, apakah obligasi yang ia beli dapat dipercaya sebagai instrumen investasi yang baik. Instrumen investasi yang baik ini dalam artian dapat memberikan tingkat pengembalian yang sesuai dengan tingkat pengembalin yang diharapkan. Untuk instrument obligasi, hal ini merupakan hal yang sangat penting dikarenakan seorang investor yang ingin membeli obligasi harus mengeluarkan dana yang cukup besar dikarenakan nilai nominal obligasi yang bisa mencapai miliaran rupiah. Dengan mengeluarkan modal yang besar, investor akan memperoleh keuntungan berupa kupon. Dikarenakan dana yang cukup besar inilah calon investor tidak akan sembarangan dalam menentukan obligasi yang akan dibeli. Biasanya calon investor akan memperhatikan obligasi tersebut berada pada peringkat obligasi apa. 


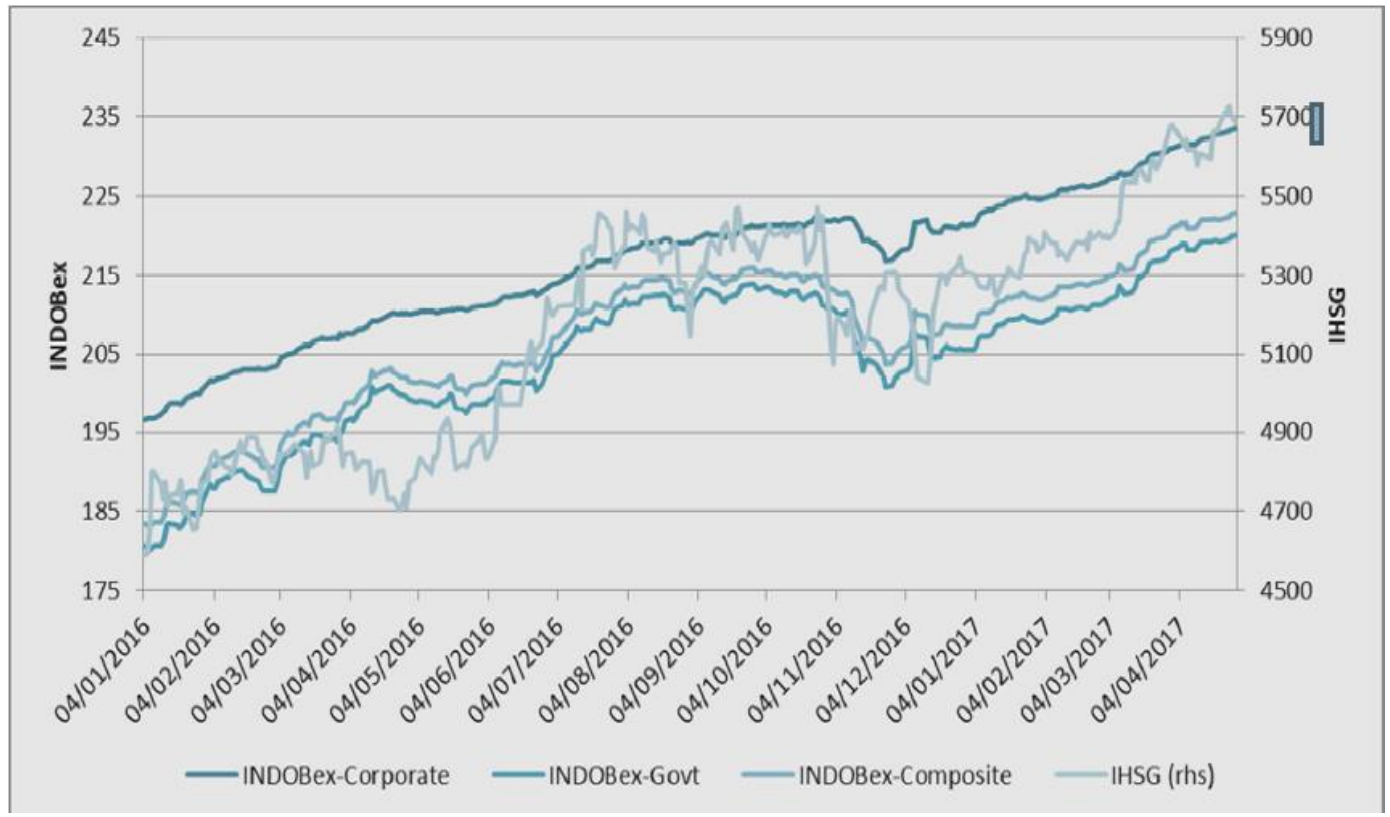

Sumber: Corporate Bond Report - MNC Securities Research Development (2017)

\section{Gambar 1. Grafik Kinerja Indeks Obligasi Dan IHSG}

Dari Gambar 2.1, grafik di atas dapat dilihat bahwa kinerja obligasi pada awal tahun 2016 berada pada poin yang rendah. Kinerja obligasi seiring dengan kepercayaan masyarakat terhadap instrumen ini sehingga memperlihatkan grafik yang semakin meningkat dari bulan ke bulan selama tahun 2016 maupun 2017. Peningkatan kinerja obligasi ini berbanding lurus dengan kinerja yang dihasilkan Indeks Harga Saham Gabungan (IHSG).

Berdasarkan uraian di atas maka peneliti tertarik untuk melakukan penelitian mengenai pengaruh terhadap peringkat obligasi di sektor perbankan dengan judul penelitian "Analisis Faktor-Faktor Yang Mempengaruhi Peringkat Obligasi Pada Perusahaan-Perusahaan Sektor Perbankan Yang Terdaftar Di Bursa Efek Indonesia Periode Tahun 2013 - 2017”.

\section{TINJAUAN PUSTAKA}

Produk - produk di pasar modal yang tercatat di Bursa Efek Indonesia (www.idx.com) yaitu:

\section{Saham}

Saham dapat didefinisikan sebagai tanda penyertaan modal seseorang atau pihak (badan usaha) dalam suatu perusahaan atau perseroan terbatas. Dengan menyertakan modal tersebut, maka pihak tersebut memiliki klaim atas pendapatan perusahaan, klaim atas asset perusahaan, dan berhak hadir dalam Rapat Umum Pemegang Saham (RUPS).

2. Obligasi

Obligasi dapat dijelaskan sebagai surat utang jangka menengah panjang yang dapat dipindahtangankan, yang berisi janji dari pihak yang menerbitkan untuk membayar imbalan berupa bunga pada periode tertentu dan melunasi pokok utang pada waktu 
yang telah ditentukan kepada pihak pembeli obligasi tersebut. Obligasi dapat diterbitkan oleh Korporasi maupun Negara.

3. Reksadana

Reksa Dana diartikan sebagai Wadah yang dipergunakan untuk menghimpun dana dari masyarakat pemodal untuk selanjutnya di investasikan dalam portofolio Efek oleh Manajer Investasi.

4. Exchange Traded Fund

ETF adalah Reksa Dana berbentuk Kontrak Investasi Kolektif yang unit penyertaannya diperdagangkan di Bursa Efek. Meskipun ETF pada dasarnya adalah reksa dana, produk ini diperdagangkan seperti saham-saham yang ada di bursa efek.

5. Derivatif

Derivatif merupakan kontrak finansial antara 2 (dua) atau lebih pihak-pihak guna memenuhi janji untuk membeli atau menjual assets/commodities yang dijadikan sebagai obyek yang diperdagangkan pada waktu dan harga yang merupakan kesepakatan bersama antara pihak penjual dan pihak pembeli. Adapun nilai di masa mendatang dari obyek yang diperdagangkan tersebut sangat dipengaruhi oleh instrumen induknya yang ada di spot market.

Berikut adalah daftar pemeringkatan obligasi menurut PEFINDO.

\section{Tabel 1. Peringkat Obligasi}

\begin{tabular}{|l|l|}
\hline Simbol & \multicolumn{1}{|c|}{ Peringkat Atas Efek Utang Jangka Panjang dan Menengah } \\
\hline AAA & $\begin{array}{l}\text { Efek utang dengan peringkat idAAA merupakan peringkat tertinggi yang } \\
\text { diberikan oleh PEFINDO. Kemampuan obligor untuk memenuhi } \\
\text { kewajiban keuangan jangka panjang atas efek utang tersebut relatif } \\
\text { dibanding obligor Indonesia lainnya adalah superior. }\end{array}$ \\
\hline AA+ & $\begin{array}{l}\text { Efek utang dengan peringkat idAA memiliki sedikit perbedaan dengan } \\
\text { peringkat tertinggi yangdiberikan, dan kemampuan Obligor untuk } \\
\text { memenuhi komitmen keuangan jangka panjang atas efek utang tersebut, } \\
\text { dibandingkan dengan Obligor lainnya di Indonesia, adalah sangat kuat. } \\
\text { Tanda Tambah (+) menunjukkan bahwa peringkat yang diberikan relatif } \\
\text { kuat dan di atas rata-rata kategori yang bersangkutan. }\end{array}$ \\
\hline AA & $\begin{array}{l}\text { Efek utang dengan peringkat idAA memiliki sedikit perbedaan dengan } \\
\text { peringkat tertinggi yang diberikan, dan kemampuan Obligor untuk } \\
\text { memenuhi komitmen keuangan jangka panjang atas efek utang tersebut, } \\
\text { dibandingkan dengan Obligor lainnya di Indonesia, adalah sangat kuat. }\end{array}$ \\
\hline AA- & $\begin{array}{l}\text { Efek utang dengan peringkat idAA memiliki sedikit perbedaan dengan } \\
\text { peringkat tertinggi yang diberikan, dan kemampuan Obligor untuk } \\
\text { memenuhi komitmen keuangan jangka panjang atas efek utang tersebut, } \\
\text { dibandingkan dengan Obligor lainnya di Indonesia, adalah sangat kuat. } \\
\text { Tanda Kurang (-) menunjukkan bahwa peringkat yang diberikan relatif } \\
\text { lemah dan di bawah rata-rata kategori yang bersangkutan. }\end{array}$ \\
\hline A+ & $\begin{array}{l}\text { Efek utang jangka panjang dengan peringkat idA mengindikasikan bahwa } \\
\text { kemampuan obligor untuk memenuhi komitmen keuangan jangka panjang } \\
\text { atas efek utang tersebut, dibandingkan dengan Obligor lainnya di } \\
\text { Indonesia, adalah kuat. Walaupun demikian, kemampuan obligor } \\
\text { mungkin akan terpengaruh oleh perubahan buruk keadaan dan kondisi } \\
\text { ekonomi, dibandingkan dengan efek utang yang peringkatnya lebih tinggi. }\end{array}$ \\
\hline
\end{tabular}




\begin{tabular}{|c|c|}
\hline & $\begin{array}{l}\text { Tanda Tambah }(+) \text { menunjukkan bahwa peringkat yang diberikan relatif } \\
\text { kuat dan di atas rata-rata kategori yang bersangkutan. }\end{array}$ \\
\hline A & $\begin{array}{l}\text { Efek utang jangka panjang dengan peringkat idA mengindikasikan bahwa } \\
\text { kemampuan obligor untuk memenuhi komitmen keuangan jangka panjang } \\
\text { atas efek utang tersebut, dibandingkan dengan Obligor lainnya di } \\
\text { Indonesia, adalah kuat. Walaupun demikian, kemampuan obligor } \\
\text { mungkin akan terpengaruh oleh perubahan buruk keadaan dan kondisi } \\
\text { ekonomi, dibandingkan dengan efek utang yang peringkatnya lebih tinggi. }\end{array}$ \\
\hline A- & $\begin{array}{l}\text { Efek utang jangka panjang dengan peringkat idA mengindikasikan bahwa } \\
\text { kemampuan obligor untuk memenuhi komitmen keuangan jangka panjang } \\
\text { atas efek utang tersebut, dibandingkan dengan Obligor lainnya di } \\
\text { Indonesia, adalah kuat. Walaupun demikian, kemampuan obligor } \\
\text { mungkin akan terpengaruh oleh perubahan buruk keadaan dan kondisi } \\
\text { ekonomi, dibandingkan dengan efek utang yang peringkatnya lebih tinggi. } \\
\text { Tanda Kurang (-) menunjukkan bahwa peringkat yang diberikan relatif } \\
\text { lemah dan di bawah rata-rata kategori yang bersangkutan. }\end{array}$ \\
\hline BBB+ & $\begin{array}{l}\text { Efek utang dengan peringkat idBBB mengindikasikan parameter proteksi } \\
\text { yang memadai relatif dibanding surat utang Indonesia lainnya. Walaupun } \\
\text { demikian, kondisi ekonomi yang buruk atau situasi yang terus berubah } \\
\text { akan dapat memperlemah kemampuan obligor terhadap komitmen } \\
\text { keuangan jangka panjangnya. Tanda Tambah (+) menunjukkan bahwa } \\
\text { peringkat yang diberikan relatif kuat dan di atas rata-rata kategori yang } \\
\text { bersangkutan. }\end{array}$ \\
\hline BBB & $\begin{array}{l}\text { Efek utang dengan peringkat idBBB mengindikasikan parameter proteksi } \\
\text { yang memadai relatif dibanding surat utang Indonesia lainnya. Walaupun } \\
\text { demikian, kondisi ekonomi yang buruk atau situasi yang terus berubah } \\
\text { akan dapat memperlemah kemampuan obligor terhadap komitmen } \\
\text { keuangan jangka panjangnya. }\end{array}$ \\
\hline BBB- & $\begin{array}{l}\text { Efek utang dengan peringkat idBBB mengindikasikan parameter proteksi } \\
\text { yang memadai relatif dibanding surat utang Indonesia lainnya. Walaupun } \\
\text { demikian, kondisi ekonomi yang buruk atau situasi yang terus berubah } \\
\text { akan dapat memperlemah kemampuan obligor terhadap komitmen } \\
\text { keuangan jangka panjangnya. Tanda Kurang (-) menunjukkan bahwa } \\
\text { peringkat yang diberikan relatif lemah dan di bawah rata-rata kategori } \\
\text { yang bersangkutan. }\end{array}$ \\
\hline BB+ & $\begin{array}{l}\text { Efek utang dengan peringkat idBB mengindikasikan parameter proteksi } \\
\text { yang sedikit lemah relatif dibandingkan efek utang Indonesia lainnya. } \\
\text { Kemampuan obligor untuk memenuhi komitmen keuangan jangka } \\
\text { panjang atas efek utang tersebut sangat terpengaruh oleh memburuknya } \\
\text { perkembangan perekonomian, bisnis, dan keuangan, yang akan dapat } \\
\text { mengakibatkan ketidakmampuan untuk memenuhi kewajiban keuangan } \\
\text { atas efek utang. Tanda Tambah (+) menunjukkan bahwa peringkat yang } \\
\text { diberikan relatif kuat dan di atas rata-rata kategori yang bersangkutan. }\end{array}$ \\
\hline BB & $\begin{array}{l}\text { Efek utang dengan peringkat idBB mengindikasikan parameter proteksi } \\
\text { yang sedikit lemah relatif dibandingkan efek utang Indonesia lainnya. } \\
\text { Kemampuan obligor untuk memenuhi komitmen keuangan jangka } \\
\text { panjang atas efek utang tersebut sangat terpengaruh oleh memburuknya } \\
\text { perkembangan perekonomian, bisnis, dan keuangan, yang akan dapat }\end{array}$ \\
\hline
\end{tabular}




\begin{tabular}{|c|c|}
\hline & $\begin{array}{l}\text { mengakibatkan ketidakmampuan untukmemenuhi kewajiban keuangan } \\
\text { atas efek utang. }\end{array}$ \\
\hline BB- & $\begin{array}{l}\text { Efek utang dengan peringkat idBB mengindikasikan parameter proteksi } \\
\text { yang sedikit lemah relatif dibandingkan efek utang Indonesia lainnya. } \\
\text { Kemampuan obligor untuk memenuhi komitmen keuangan jangka } \\
\text { panjang atas efek utang tersebut sangat terpengaruh oleh memburuknya } \\
\text { perkembangan perekonomian, bisnis, dan keuangan, yang akan dapat } \\
\text { mengakibatkan ketidakmampuan untuk memenuhi kewajiban keuangan } \\
\text { atas efek utang. Tanda Kurang (-) menunjukkan bahwa peringkat yang } \\
\text { diberikan relatif lemah dan di bawah rata-rata kategori yang bersangkutan. }\end{array}$ \\
\hline B+ & $\begin{array}{l}\text { Efek utang dengan peringkat idB mengindikasikan parameter proteksi } \\
\text { yang lemah relatif dibanding efek utang Indonesia lainnya. Walaupun } \\
\text { obligor pada saat ini masih memiliki kemampuan untuk memenuhi } \\
\text { komitmen keuangan jangka panjang atas efek utang tersebut, pemburukan } \\
\text { kondisi perekonomian, bisnis, dan keuangan akan berakibat pada } \\
\text { melemahnya kemampuan atau keinginan obligor untuk memenuhi } \\
\text { komitmen-komitmen keuangan atas efek utang tersebut. Tanda Tambah } \\
\text { (+) menunjukkan bahwa peringkat yang diberikan relatif kuat dan di atas } \\
\text { rata-rata kategori yang bersangkutan. }\end{array}$ \\
\hline B & $\begin{array}{l}\text { Efek utang dengan peringkat idB mengindikasikan parameter proteksi } \\
\text { yang lemah relatif dibanding efek utang Indonesia lainnya. Walaupun } \\
\text { obligor pada saat ini masih memiliki kemampuan untuk memenuhi } \\
\text { komitmen keuangan jangka panjang atas efek utang tersebut, pemburukan } \\
\text { kondisiperekonomian, bisnis, dan keuangan akan berakibat pada } \\
\text { melemahnya kemampuan atau keinginan obligor untuk memenuhi } \\
\text { komitmen-komitmen keuangan atas efek utang tersebut. }\end{array}$ \\
\hline B- & $\begin{array}{l}\text { Efek utang dengan peringkat idB mengindikasikan parameter proteksi } \\
\text { yang lemah relatif dibanding efek utang Indonesia lainnya. Walaupun } \\
\text { obligor pada saat ini masih memiliki kemampuan untuk memenuhi } \\
\text { komitmen keuangan jangka panjang atas efek utang tersebut, pemburukan } \\
\text { kondisi perekonomian, bisnis, dan keuangan akan berakibat pada } \\
\text { melemahnya kemampuan atau keinginan obligor untuk memenuhi } \\
\text { komitmen-komitmen keuangan atas efek utang tersebut. Tanda Kurang (-) } \\
\text { menunjukkan bahwa peringkat yang diberikan relatif lemah dan di bawah } \\
\text { rata-rata kategori yang bersangkutan. }\end{array}$ \\
\hline CCC & $\begin{array}{l}\text { Efek utang dengan peringkat idCCC pada saat ini rentan untuk gagal } \\
\text { bayar dan tergantung pada kondisi bisnis dan keuangan yang lebih } \\
\text { menguntungkan untuk dapat memenuhi komitmen keuangan jangka } \\
\text { panjangnya atas efek utang. }\end{array}$ \\
\hline \multirow[t]{2}{*}{ D } & $\begin{array}{l}\text { Efek utang diberi peringkat idD pada saat gagal bayar, atau gagal bayar } \\
\text { atas efek utang terjadi dengan sendirinya pada saat pertama kali timbulnya } \\
\text { peristiwa gagal bayar atas efek utang tersebut. }\end{array}$ \\
\hline & $\begin{array}{l}\text { Peringkat dari idAA sampai dengan idB dapat dimodifikasi dengan } \\
\text { menambahkan tanda tambah }(+) \text { atau tanda kurang }(-) \text { untuk menunjukkan } \\
\text { kekuatan relatif obligor dalam kategori peringkat tertentu. }\end{array}$ \\
\hline
\end{tabular}

Sumber: www.PEFINDO.com (2018) 


\section{KERANGKA KONSEPTUAL}

\section{Peringkat Obligasi}

Peringkat Obligasi adalah salah satu indikator penting mengenai kualitas kredit perusahaan. Peringkat obligasi ini diperoleh dari data yang telah dipublikasikan oleh pemeringkat obligasi yaitu PEFINDO.

\section{Kapitalisasi}

Menurut Frank (1999) Rasio Kapitaliasasi untuk menentukan baik batasan dimana perusahaan memperdagangkan ekuitasnya maupun pengungkit keuangan yang dihasilkan. Asumsinya adalah semakin besar stabilitas industry dan laba serta arus kas perusahaan, perusahaan semakin dapat menerima risiko yang berhubungan dengan pengungkit keuangan, dan akan semakin tinggi pula rasio hutang terhadap total kapitalisasi yang diizinkan.

Hasil penelitian ini menunjukkan adanya pengaruh negatif, di mana semakin rendah capitalization yang dimiliki oleh bank penerbit obligasi, maka akan semakinsemakin tinggi nilai capitalization yang dimiliki oleh bank penerbit obligasi, semakin rendah peringkat obligasi yang diterima, Nelly dan Hendro (2013).

Pada penelitian ini Kapitalisasi diukur dengan Primary Ratio dengan rumus:

$$
\text { Primary Ratio }=\frac{\text { Modal }}{\text { Total Asset }}
$$

Rumus ini juga digunakan pada penelitian Thamida dan Lukman (2013)

\section{Likuiditas}

Menurut Brigham dan Houston (2012: 134) Rasio Lukuiditas merupakan rasio yang menunjukkan hubungan antara kas dan asset lancar perusahaan lainnya dengan kewajiban lancarnya. Jika suatu perusahaan mengalami kesulitan keuangan, perusahaan mulai lambat bayar tagihan hutang usaha, pinjaman bank, dan kewajiban lainnya yang akan meningkatkan kewajiban lancar. Salah satunya membayar obligasi yang diterbitkan oleh perusahaan.

Nelly dan Hendro (2013) memberikan hasil penelitian tidak terdapat pengaruh yang signifikan terhadap peringkat obligasi.

Pada penelitian ini Likuiditas diukur dengan rumus Current Ratio (Rasio Lancar). Ratio ini berguna untuk mengukur kemampuan perusahaan untuk membiayai kewajiban lancar dengan aset lancarnya. Rumus yang digunakan pada penelitian ini:

$$
\text { Current Ratio }=\frac{\text { Aset Lancar }}{\text { Kewajiban Lanear }}
$$

\section{Profitabilitas}

Menurut Brigham dan Houston (2006:107) Rasio Profitabilitas adalah sekelompok rasio yang menunjukkan gabungan efek - efek dari likuiditas, manajemen aktiva, dan utang pada hasil - hasil operasi. Rasio - Rasio yang telah dibahas sejauh ini dapat memberikan petunjuk - petunjuk yang berguna dalam menilai keefektivan dari operasi sebuah perusahaan, tetapi rasio profitabilitas akan menunjukkan kombinasi efek dari likuiditas, manajemen aktiva, dan utang pada hasil operasi.

Nelly dan Hendro (2013) memberikan hasil penelitian Pengujian terhadap variabel profitabilitas menunjukkan bahwa tidak terdapat pengaruh yang signifikan terhadap penentuan peringkat obligasi.

Pada penelitian ini profitabilitas diukur dengan Net Profit Margin rasio ini digunakan untuk membandingkan laba setelah bunga dan pajak terhadap penjualan 
bersih untuk menunjukkan berapa besar bagian dari penjualan bersih yang menjadi laba setelah bunga dan pajak. Rumus yang digunakan pada penelitian ini:

$$
\text { Net Profit Margin }=\frac{\text { Laba Bersih Setelah Pajak }}{\text { Penjwalan Bersih }}
$$

Berdasarkan uraian di atas, maka kerangka konseptual dapat penulis gambarkan sebagai berikut:

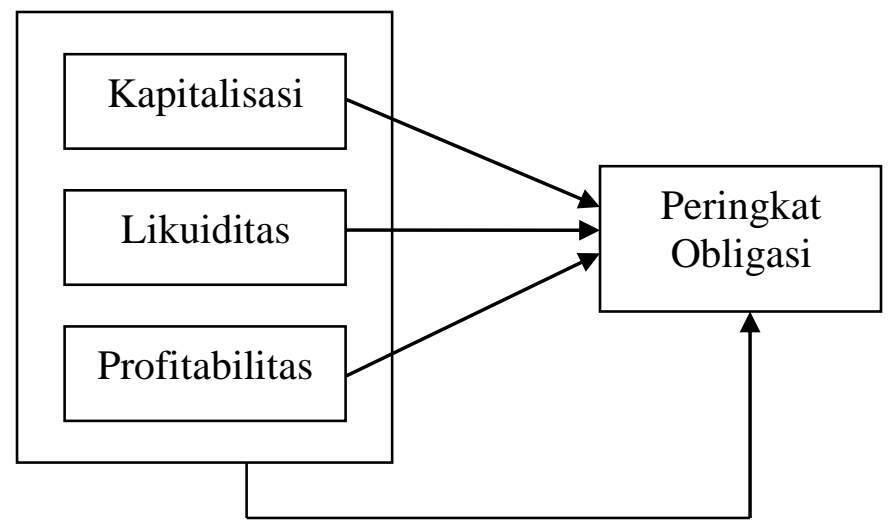

Sumber : Diolah peneliti (2019)

\section{Gambar 2. Kerangka Konseptual}

\section{HIPOTESIS}

Berdasarkan uraian di atas, maka peneliti merumuskan sebanyak 3 (tiga) hipotesis yaitu:

H1 : Terdapat pengaruh Kapitalisasi terhadap peringkat obligasi pada perusahaan sektor perbankan yang terdaftar di Bursa Efek Indonesia 2015-2018.

$\mathrm{H} 2$ : Terdapat pengaruh Likuiditas terhadap peringkat obligasi pada perusahaan sektor perbankan yang terdaftar di Bursa Efek Indonesia tahun 2015-2018.

H3 : Terdapat pengaruh Profitabilitas terhadap peringkat obligasi pada perusahaan sektor perbankan yang terdaftar di Bursa Efek Indonesia tahun 2015-2018.

\section{METODE PENELITIAN}

Penelitian ini merupakan penelitian kuantitatif dimana peneliti mengumpulkan seluruh data sekunder yaitu data keuangan untuk kemudian diolah dan dianalisis. Data sekunder ini diperoleh dari sumber resmi yang dipublikasikan Bursa Efek Indonesia.

Populasi pada penelitian ini adalah seluruh perusahaan perbankan yang terdaftar di BEI yang obligasinya telah di-rating oleh lembaga pemeringkat obligasi PEFINDO. Populasi pada penelitian ini sebanyak 55 perusahaan sedangkan sampel dalam penelitian ini sebanyak 22 perusahaan.

Sampel tersebut dipilih dengan metode purposive sampling dengan kriteria sebagai berikut: (1) Perusahaan berdiri dan beroperasi selama tahun 2015-2018, (2) Perusahaan memiliki ketersediaan dan kelengkapan data yang dibutuhkan dalam penelitian, (3) Perusahaan yang bergerak di sektor perbankan, (4) Tidak suspended selama tahun 2015-2018, dan (5) Perusahaan yang telah tercatat di Bursa Efek Indonesia. 
Pengujian data yang dilakukan dalam penelitian ini menggunakan uji asumsi klasik yaitu dengan melakukan uji normalitas, uji multikolinearitas, uji heteroskedastisitas, dan uji autokorelasi. Sedangkan pengujian hipotesis dilakukan dengan menggunakan uji F dan uji t. Dalam melakukan analisis peneliti menggunakan aplikasi SPSS.

\section{HASIL DAN PEMBAHASAN}

Adapun perusahaan sampel dalam penelitian adalah sebagai berikut:

Tabel 2. Sampel Penelitian

\begin{tabular}{|c|c|c|}
\hline No & Kode Emiten & Nama Perusahaan \\
\hline 1 & AGRO & Bank Rakyat Indonesia Agroniaga, Tbk. \\
\hline 2 & BACA & Bank Capital Indonesia, Tbk. \\
\hline 3 & BBCA & Bank Central Asia Tbk \\
\hline 4 & BBKP & Bank Bukopin, Tbk. \\
\hline 5 & BBNI & Bank Negara Indonesia (Persero), Tbk. \\
\hline 6 & BBRI & Bank Rakyat Indonesia (Persero), Tbk. \\
\hline 7 & BBTN & Bank Tabungan Negara (Persero), Tbk. \\
\hline 8 & BBYB & Bank Yudha Bhakti, Tbk. \\
\hline 9 & BDMN & Bank Danamon Indonesia, Tbk. \\
\hline 10 & BJBR & Bank Pembangunan Daerah Jawa Barat dan Banten, Tbk. \\
\hline 11 & BKSW & Bank QNB Indonesia, Tbk. \\
\hline 12 & BMRI & Bank Mandiri (Persero), Tbk. \\
\hline 13 & BNGA & Bank CIMB Niaga, Tbk. \\
\hline 14 & BNII & Bank Maybank Indonesia, Tbk. \\
\hline 15 & BNLI & Bank Permata, Tbk. \\
\hline 16 & BRIS & Bank BRI Syariah \\
\hline 17 & BVIC & Bank Victoria International, Tbk. \\
\hline 18 & MAYA & Bank Mayapada Internasional, Tbk. \\
\hline 19 & MEGA & Bank Mega, Tbk. \\
\hline 20 & NISP & Bank OCBC NISP, Tbk. \\
\hline 21 & PNBN & Bank Pan Indonesia, Tbk. \\
\hline 22 & PNBS & Bank Panin Dubai Syariah, Tbk. \\
\hline
\end{tabular}

Data diolah oleh peneliti (2019)

Berikut adalah data seluruh perusahaan yang menjadi sampel dalam penelitian ini, beserta data mentah berupa Kapitalisasi sebagai X1, Likuiditas sebagai X2, Profitabilitas sebagai X3, dan Peringkat Obligasi sebagai Y.

Tabel 3. Data Kapitalisasi, Likuiditas, Profitabilitas dan Peringkat Obligasi 2015-2018

\begin{tabular}{|c|c|c|c|c|c|c|}
\hline No & $\begin{array}{c}\text { Kode } \\
\text { Emiten }\end{array}$ & Tahun & $\begin{array}{c}(\mathbf{X 1}) \\
\text { Kapitalisasi }\end{array}$ & $\begin{array}{c}(\mathbf{X 2}) \\
\text { Likuiditas }\end{array}$ & $\begin{array}{c}\text { Y } \\
\text { Profitabilitas }\end{array}$ & $\begin{array}{c}\text { Peringkat } \\
\text { Obligasi }\end{array}$ \\
\hline 1 & AGRO & 2015 & 0.1372 & 1,1759 & 0.1023 & - \\
\hline
\end{tabular}




\begin{tabular}{|c|c|c|c|c|c|c|}
\hline & & 2016 & 0.1347 & 1,2021 & 0.1067 & - \\
\hline & & 2017 & 0.1097 & 1,2822 & 0.1122 & AA \\
\hline & & 2018 & 0.0190 & 0.8320 & 0.3021 & AA \\
\hline \multirow[t]{4}{*}{2} & BACA & 2015 & 0.0527 & 1,0531 & 0.0813 & $\mathrm{BBB}+$ \\
\hline & & 2016 & 0.0495 & 1,1108 & 0.0755 & $\mathrm{BBB}+$ \\
\hline & & 2017 & 0.0861 & 1,1281 & 0.0668 & $\mathrm{BBB}+$ \\
\hline & & 2018 & 0.0824 & 1,0988 & 0.2471 & BBB- \\
\hline \multirow[t]{4}{*}{3} & BBCA & 2015 & 0.0026 & 1,1001 & 0.3831 & - \\
\hline & & 2016 & 0.0023 & 1,0142 & 0.4092 & - \\
\hline & & 2017 & 0.0021 & 1,0096 & 0.4337 & - \\
\hline & & 2018 & 0.1840 & 1,2077 & 0.5708 & AA \\
\hline \multirow[t]{4}{*}{4} & BBKP & 2015 & 0.0119 & 1,1131 & 0.1161 & $\mathrm{~A}+$ \\
\hline & & 2016 & 0.0106 & 1,1013 & 0.1235 & $\mathrm{~A}+$ \\
\hline & & 2017 & 0.0105 & 1,0361 & 0.0434 & $\mathrm{~A}+$ \\
\hline & & 2018 & 0.0899 & 0.7799 & 0.0733 & A- \\
\hline \multirow[t]{4}{*}{5} & BBNI & 2015 & 0.0178 & 1,1860 & 0.3576 & - \\
\hline & & 2016 & 0.0150 & 1,1726 & 0.3804 & AAA \\
\hline & & 2017 & 0.0128 & 1,1565 & 0.4312 & AAA \\
\hline & & 2018 & 0.1365 & 1,1531 & 0.2788 & AAA \\
\hline \multirow[t]{4}{*}{6} & BBRI & 2015 & 0.1288 & 1,2173 & 0.4360 & AAA \\
\hline & & 2016 & 0.1463 & 1,2414 & 0.4009 & AAA \\
\hline & & 2017 & 0.1486 & 1,2307 & 0.3978 & AAA \\
\hline & & 2018 & 0.1429 & 0.1681 & 0.4174 & AAA \\
\hline \multirow[t]{4}{*}{7} & BBTN & 2015 & 0.0807 & 1,2554 & 0.2717 & AA \\
\hline & & 2016 & 0.0893 & 1,2293 & 0.3208 & $\mathrm{AA}+$ \\
\hline & & 2017 & 0.0829 & 1,2420 & 0.3241 & $\mathrm{AA}+$ \\
\hline & & 2018 & 0.0778 & 0.2497 & 0.2783 & $\mathrm{AA}+$ \\
\hline \multirow[t]{4}{*}{8} & BBYB & 2015 & 0.1069 & 1,0743 & 0.1446 & - \\
\hline & & 2016 & 0.1555 & 1,1376 & 0.2781 & - \\
\hline & & 2017 & 0.1351 & 1,1081 & 0.0466 & $\mathrm{BBB}+$ \\
\hline & & 2018 & 0.1324 & 0.1613 & -0.4784 & - \\
\hline \multirow[t]{4}{*}{9} & BDMN & 2015 & 0.0314 & 1,3087 & 0.1742 & AAA \\
\hline & & 2016 & 0.0339 & 1,3057 & 0.1939 & AAA \\
\hline & & 2017 & 0.0331 & 1,3417 & 0.2593 & AAA \\
\hline & & 2018 & 0.2246 & 1,3053 & 0.2884 & AAA \\
\hline \multirow[t]{4}{*}{10} & BJBR & 2015 & 0.0875 & 1,1788 & 0.2753 & AA- \\
\hline & & 2016 & 0.0946 & 1,1713 & 0.4509 & AA- \\
\hline & & 2017 & 0.0879 & 1,2191 & 0.1925 & AA- \\
\hline & & 2018 & 0.0939 & 0.8744 & 0.2389 & AA- \\
\hline \multirow[t]{4}{*}{11} & BKSW & 2015 & 0.0941 & 1,0568 & 0.1076 & AA \\
\hline & & 2016 & 0.0929 & 1,1206 & -0.4226 & AA \\
\hline & & 2017 & 0.1620 & 1,1086 & -31.681 & AA \\
\hline & & 2018 & 0.2281 & 1,7168 & 0.0481 & $\mathrm{AA}$ \\
\hline \multirow[t]{4}{*}{12} & BMRI & 2015 & 0.0128 & 1,3300 & 0.4663 & AAA \\
\hline & & 2016 & 0.0112 & 1,3292 & 0.2827 & AAA \\
\hline & & 2017 & 0.0104 & 1,1948 & 0.3839 & AAA \\
\hline & & 2018 & 0.1538 & 1,0869 & 0.4733 & AAA \\
\hline \multirow[t]{2}{*}{13} & BNGA & 2015 & 0.0068 & 1,2153 & 0.0376 & AAA \\
\hline & & 2016 & 0.0067 & 1,2059 & 0.1721 & AAA \\
\hline
\end{tabular}




\begin{tabular}{|c|c|c|c|c|c|c|}
\hline & & 2017 & 0.0061 & 1,1922 & 0.2401 & AAA \\
\hline & & 2018 & 0.1484 & 1,1263 & 0.2899 & $\overline{\mathrm{AAA}}$ \\
\hline \multirow[t]{4}{*}{14} & BNII & 2015 & 0.0233 & 1,1878 & 0.1918 & AAA \\
\hline & & 2016 & 0.0220 & 1,1828 & 0.2977 & $\overline{\mathrm{AAA}}$ \\
\hline & & 2017 & 0.0212 & 1,1681 & 0.2416 & AAA \\
\hline & & 2018 & 0.1413 & 1,2517 & 0.2793 & AAA \\
\hline \multirow[t]{4}{*}{15} & BNLI & 2015 & 0.1030 & 1,0298 & 0.0399 & AAA \\
\hline & & 2016 & 0.1165 & 0.9179 & $-1,1019$ & $\overline{\mathrm{AAA}}$ \\
\hline & & 2017 & 0.1450 & 0.9637 & 0.1433 & AAA \\
\hline & & 2018 & 0.1468 & 0.9623 & 0.1669 & $\mathrm{AA}+$ \\
\hline \multirow[t]{4}{*}{16} & BRIS & 2015 & 0.0817 & 4,9822 & 0.0506 & - \\
\hline & & 2016 & 0.0715 & 4,8908 & 0.0646 & - \\
\hline & & 2017 & 0.0627 & 4,4014 & 0.0359 & AA+ \\
\hline & & 2018 & 0.1326 & 0.8449 & 0.0591 & - \\
\hline \multirow[t]{4}{*}{17} & BVIC & 2015 & 0.0909 & 1,1921 & 0.2190 & A- \\
\hline & & 2016 & 0.1010 & 1,1826 & 0.3305 & A- \\
\hline & & 2017 & 0.0987 & 1,2066 & 0.2974 & A- \\
\hline & & 2018 & 0.0930 & 0.6190 & 0.1722 & A- \\
\hline \multirow[t]{4}{*}{18} & MAYA & 2015 & 0.0970 & 0.9011 & 0.3846 & - \\
\hline & & 2016 & 0.0106 & 1,1292 & 0.3393 & - \\
\hline & & 2017 & 0.0094 & 1,1425 & 0.2598 & $\mathrm{~A}$ \\
\hline & & 2018 & 0.1240 & 1,1530 & 0.1473 & BBB \\
\hline \multirow[t]{4}{*}{19} & MEGA & 2015 & 0.1688 & 1,0917 & 0.3187 & - \\
\hline & & 2016 & 0.1739 & 1,1169 & 0.3320 & $\mathrm{~A}+$ \\
\hline & & 2017 & 0.1675 & 0.7751 & 0.3705 & $\mathrm{~A}+$ \\
\hline & & 2018 & 0.1645 & 1,0860 & 0.4552 & - \\
\hline \multirow[t]{4}{*}{20} & NISP & 2015 & 0.1362 & 1,2475 & 0.3396 & AAA \\
\hline & & 2016 & 0.1412 & 1,2087 & 0.3319 & $\overline{\mathrm{AAA}}$ \\
\hline & & 2017 & 0.1417 & 1,2044 & 0.3603 & $\overline{\mathrm{AAA}}$ \\
\hline & & 2018 & 0.1407 & 1,2037 & 0.4136 & AAA \\
\hline \multirow[t]{4}{*}{21} & PNBN & 2015 & 0.1682 & 1,2216 & 0.2177 & $\mathrm{AA}$ \\
\hline & & 2016 & 0.1717 & 1,2605 & 0.2982 & $\mathrm{AA}$ \\
\hline & & 2017 & 0.1699 & 1,2552 & 0.2321 & $\mathrm{AA}$ \\
\hline & & 2018 & 0.1967 & 0.7409 & 0.3555 & AA- \\
\hline \multirow[t]{4}{*}{22} & PNBS & 2015 & 0.1620 & 1,1836 & 0.1848 & $\mathrm{~A}+$ \\
\hline & & 2016 & 0.1356 & 1,1235 & 0.0662 & $\mathrm{~A}+$ \\
\hline & & 2017 & 0.0318 & 0.9957 & $-3,0937$ & AA- \\
\hline & & 2018 & 0.1902 & 2,9765 & 0.0347 & $\mathrm{~A}+$ \\
\hline
\end{tabular}

Sumber: www.idx.co.id (2019)

Dari data tabel 3 di atas dapat dilihat data kapitalisasi, likuiditas, profitabilitas dan peringkat obligasi dari perusahaan sampel mengalami fluktuasi setiap tahunnya di tahun 20152018.

Tingkat kapitalisasi terendah pada tahun penelitian diperoleh BBCA sebesar 0,0021 di tahun 2017 dan tingkat kapitalisasi tertinggi diperoleh BKSW sebesar 0,2281 di tahun 2018.

Tingkat likuditas terendah pada tahun penelitian diperoleh BBYB sebesar 0,1613 di tahun 2018 sedangkan tingkat likuiditas tertinggi diperoleh BRIS sebesar 4,9822 di tahun 2015.

Tingkat profitabilitas terendah pada tahun penelitian diperoleh BKSW sebesar -3,1681 di tahun 2017 sedangkan tingkat profitabilitas tertinggi diperoleh BBCA sebesar 0,5708 di tahun 2018. Peringkat obligasi terendah pada penelitian yaitu BBB dengan 1 obligasi 
perusahaan sampel dan peringkat obligasi tertinggi yaitu AAA dengan jumlah 30 obligasi perusahaan sampel. Dari data di atas juga dapat dilihat sebanyak 16 obligasi masih belum mendapat peringkat obligasi.

\section{Hasil UJI F}

\section{Tabel 4. Hasil Uji F}

ANOVA $^{\mathrm{b}}$

\begin{tabular}{|ll|r|r|r|r|r|}
\hline Model & & Sum of Squares & df & Mean Square & F & Sig. \\
\hline 1 & Regression & .300 & 3 & .100 & .656 & $.581^{\mathrm{a}}$ \\
& Residual & 12.791 & 84 & .152 & & \\
& 13.091 & 87 & & & \\
\hline
\end{tabular}

a. Predictors: (Constant), LnProfitabilitas, LnKapitalisasi, Lnlikuiditas

b. Dependent Variable: Peringkat

Sumber: Diolah dengan menggunakan SPSS (2019)

Dari tabel 4 di atas terdapat hasil uji $\mathrm{F}$ dengan nilai signifikansi sebesar 0,581 lebih besar dari 0,05 sehingga dapat disimpulkan bahwa variabel independen secara simultan tidak terdapat pengaruh signifikan terhadap variabel dependen dalam penelitian ini.

\section{Hasil UJI t}

Tabel 5. Hasil Uji t

\begin{tabular}{|c|c|c|c|c|c|c|c|c|}
\hline \multicolumn{9}{|c|}{ Coefficients $^{a}$} \\
\hline \multirow{2}{*}{\multicolumn{2}{|c|}{ Model }} & \multicolumn{2}{|c|}{$\begin{array}{c}\text { Unstandardized } \\
\text { Coefficients }\end{array}$} & \multirow{2}{*}{$\begin{array}{c}\text { Standardized } \\
\text { Coefficients } \\
\text { Beta }\end{array}$} & \multirow[b]{2}{*}{$\mathrm{t}$} & \multirow[b]{2}{*}{ Sig. } & \multicolumn{2}{|c|}{$\begin{array}{l}\text { Collinearity } \\
\text { Statistics }\end{array}$} \\
\hline & & $\mathrm{B}$ & Error & & & & Tolerance & VIF \\
\hline 1 & (Constant) & .902 & .140 & & 6.461 & .000 & & \\
\hline & LnKapitalisasi & .045 & .036 & .137 & 1.268 & .208 & .997 & 1.003 \\
\hline & Lnlikuiditas & -.035 & .098 & -.042 & -.358 & .721 & .856 & 1.168 \\
\hline & LnProfitabilitas & -.029 & .057 & -.060 & -.516 & .607 & .858 & 1.166 \\
\hline
\end{tabular}

a. Dependent Variable:Peringkat

Sumber: Diolah dengan menggunakan SPSS (2019)

Dari tabel 5 di atas, dapat dilihat bahwa nilai signifikansi kapitalisasi sebesar 0,208 lebih besar dari 0,05 menunjukkan bahwa tidak terdapat pengaruh signifikan terhadap peringkat obligasi. Tingkat signifikansi likuiditas dengan nilai sebesar 0,721 lebih besar dari 0,05 menunjukkan bahwa tidak terdapat pengaruh signifikan terdapat peringkat obligasi. Tingkat signifikansi profitabilitas dengan nilai sebesar 0,607 lebih besar dari 0,05 menunjukkan bahwa tidak terdapat pengaruh signifikan terhadap peringkat obligasi. 


\section{KESIMPULAN}

Dari hasil penelitian ini dapat disimpulkan bahwa tidak terdapat pengaruh signifikan variabel independen pertama (X1) yaitu kapitalisasi terhadap peringkat obligasi perusahaan perbankan yang terdaftar di Bursa Efek Indonesia pada periode tahun 2015-2018.

Dari hasil penelitian ini dapat disimpulkan bahwa tidak terdapat pengaruh signifikan variabel independen pertama (X1) yaitu likuiditas terhadap peringkat obligasi perusahaan perbankan yang terdaftar di Bursa Efek Indonesia pada periode tahun 20152018.

Dari hasil penelitian ini dapat disimpulkan bahwa tidak terdapat pengaruh signifikan variabel independen pertama (X1) yaitu profitabilitas terhadap peringkat obligasi perusahaan perbankan yang terdaftar di Bursa Efek Indonesia pada periode tahun 2015-2018.

Bagi peneliti selanjutnya, dapat menambah variabel lainnya untuk melihat faktor-faktor yang dapat mempengaruhi peringkat obligasi pada perusahaan sektor lainnya agar memperolah hasil yang lebih general.

Bagi perusahaan penerbit obligasi, dapat meningkatkan kinerja nya untuk mendapat peringkat obligasi yang tinggi dikarenakan calon investor akan melihat terlebih dahulu peringkat obligasi yang ditawarkan.sebelum melihat informasi lainnya mengenai perusahaan penerbit obligasi.

\section{DAFTAR PUSTAKA}

Amalia, Ninik. (2013). Pemeringkatan Obligasi Pt Pefindo : Berdasarkan Informasi Keuangan. Vol. 2 Accounting Analysis Journal. Universitas Negeri Semarang.

Arikunto, Suharsimi. (2002). Prosedur Penelitian Suatu Pendekatan Praktek Edisi Revisi V. Jakarta: PT Rineka Cipta.

Arikunto, Suharsimi. (2003). Manajemen Penelitian. Jakarta: PT Rineka Cipta

Arikunto, Suharsimi. 2013. Manajemen Penelitian. Jakarta: PT Rineka Cipta

Brigham, Eugene F., Dan Joel F. Houston. (2006). Dasar-Dasar Manajemen Keuangan. Terjemahan Oleh Ali Akbar Yulianto. Jakarta: Salemba Empat.

Fabozzi, Frank J. (1999). Manajemen Investasi. Terjemahan Oleh Tim Penterjemah Salemba Empat. Jakarta: Salemba Empat.

Horne, James C, Van., Dan John M. Wachowicz, Jr. (2009). Prinsip - Prinsip Manajemen Keuangan. Terjemahan Oleh Dewi Fitriasari Dan Deny Arnos Kwary. Jakarta: Salemba Empat.

Martono, Su., Dan Agus Harjito. (2003). Manajemen Keuangan. Yogyakarta: Ekonisia.

Sartono, Agus. (2008). Manajemen Keuangan Teori Dan Aplikasi Edisi 4. Yogyakarta: Bpfe- Yogyakarta. 
Siamat, Dahlan. (2004). Manajemen Lembaga Keuangan Edisi Keempat. Jakarta: Fakultas Ekonomi Universitas Indonesia.

Thamida, Nelly., Dan Hendro Lukman. (2013). Analisis Faktor-Faktor Yang Mempengaruhi Peringkat Obligasi Pada Industri Perbankan Yang Terdaftar Di Bursa Efek Indonesia Periode 2008-2012. Jurnal Akuntansi Volume Xvii. Blesia, Jhon Urasti., Dan Dita Ria Pramudika. 2016. Key Aspects Of The Bond Ratings In Indonesia. Asian Journal Of Economics, Business And Accounting Volume 3.

Internet:

https://investasi.kontan.co.id/news/bunga-obligasi-teranyar-emiten-perbankan-dipatoklebih-tinggi diakses pada tanggal 20 Januari 2019

www.pefindo.com diakses pada tanggal 23 Januari 2019

http://www.idx.co.id/produk/surat-utang-obligasi/ diakses pada tanggal 20 November 2018

http://www.ibpa.co.id diakses pada tanggal 10 Oktober 2018

https://www.google.co.id/url?sa=t\&source=web\&rct=i\&url=https://www.mncsekuritas.i d/po-content/poupload/ObligasiGlobalMediaCom/Report.pdf\&ved=2ahUKEwik4I7y1tjdAhVFgI8KH WDXDnsQFjABegQIBxAB\&usg=AOvVaw3_CGeb5WXxss9a1ooUyXgL diakses pada tanggal 10 Februari 2019

www.sciencedomain.org. diakses pada tanggal 26 September 2018

http://journal.unnes.ac.id/sju/index.php/aaj. diakses pada tanggal 26 September 2018

http://portal.kopertis3.or.id/bitstream/123456789/2013/1/hendro-ja17.02.pdf. diakses pada tanggal 17 September 2018 